\title{
HUBUNGAN ANTARA BUDAYA ORGANISASI DAN KEPUASAN KERJA DENGAN KOMITMEN TERHADAP ORGANISASI
}

\author{
Herman \\ Dosen Tetap Fakultas Ekonomi Universitas Pakuan
}

\begin{abstract}
Abstrak
Tujuan penelitian ini adalah untuk mengetahui ada tidaknya hubungan antara budaya organisasi dan kepuasan kerja dengan komitmen terhadap organisasi (Studi Pada Karyawan Tous Les Jours Bakery). Populasi dalam penelitian ini adalah keseluruhan karyawan Tous Les Jours Bakery sebanyak 364 orang, sedangkan yang akan dijadikan sebagai sampel penelitian adalah karyawan bagian Kitchen Staff yang berjumlah 200 orang. Sampel mengunakan rumus Slovin yaitu sebanyak 133 orang. Instrumen penelitian adalah kuesioner. Data yang terkumpul selanjutnya diolah menggunakan teknik analisis korelasi dengan bantuan perangkat lunak SPSS (Statistical Package for Social Science). Hasil penelitian menunjukkan bahwa: Pertama, budaya organisasi dengan komitmen terhadap organisasi mempunyai hubungan sangat signifikan dan mempunyai kontribusi sebesar $11,3 \%$. Kedua, kepuasan kerja dengan komitmen terhadap organisasi mempunyai hubungan sangat signifikan dan mempunyai kontribusi sebesar 21,7\%. Ketiga, budaya organisasi dan kepuasan kerja secara bersama-sama mempunyai hubungan sangat signifikan dan mempunyai kontribusi sebesar $25,7 \%$, sisanya $74,3 \%$ ditentukan oleh variable lainnya yang tidak diteliti.
\end{abstract}

Kata kunci: Budaya Organisasi, Kepuasan Kerja dan Komitmen Terhadap Organisasi.

\begin{abstract}
The purpose of this study was to determine whether there is a relationship between organizational culture and job satisfaction with a commitment to the organization (Study Tous Les Jours Employees In Bakery). The population in this study was overall Tous Les Jours Bakery employees as much as 364 people, while that will serve as the study sample were employees of the Kitchen staff totaling 200 people. Slovin formula samples using as many as 133 people. The research instrument was a questionnaire. The collected data was then processed using correlation analysis techniques with the help of software SPSS (Statistical Package for Social Science). The results showed that: First of organizational culture on organizational commitment has a significant relationship and has a contribution of 11.3\%. Both job satisfaction and commitment to the organization has a very significant relationship and has a contribution of $21.7 \%$. The third organizational culture and job satisfaction together have a very significant relationship and have contributed $25.7 \%$, the remaining $74.3 \%$ is determined by other variables not examined.
\end{abstract}

Keywords: Organizational Culture, Job Satisfaction and Commitment to the Organization.

\section{Pendahuluan}

Sumber daya manusia (SDM) merupakan salah satu aset penting organisasi yang dapat menggerakkan sumber daya lainnya. Sumber daya manusia dapat mempengaruhi efisiensi dan efektivitas organisasi. Hal tersebutlah yang membuat para pebisnis usaha makanan cepat saji sadar akan nilai investasi karyawan sebagai sumber daya manusia. Dimana saat ini mengumpulkan tenaga kerja yang cakap dan berkinerja baik semakin sulit dilakukan, terlebih lagi mempertahankan yang sudah ada. Mereka harus memprioritaskan untuk menemukan, mempekerjakan, memotivasi, melatih, mengembangkan karyawan yang paling dekat dengan budaya makanan cepat saji dan performa yang dikehendaki, serta mempertahankan karyawan berkualitas.

Perpindahan karyawan (employee turnover) adalah suatu fenomena yang sering terjadi dalam industri makanan 
cepat saji. Turnover dapat diartikan sebagai pergerakan tenaga kerja keluar dari organisasi. Turnover mengarah pada kenyataan akhir yang dihadapi suatu organisasi berupa jumlah karyawan yang meninggalkan organisasi pada periode tertentu sedangkan keinginan karyawan untuk berpindah (turnover intentions) mengacu pada hasil evaluasi individu mengenai kelanjutan hubungan dengan organisasi yang belum diwujudkan dalam tindakan pasti meninggalkan organisasi.

Turnover karyawan juga terjadi pada salah satu perusahaan dalam industri makanan cepat saji, Tous Les Jours Bakery. Tous Les Jours Bakery yang didirikan pada bulan Agustus tahun 2011 merupakan salah satu bagian dari CJ Group Indonesia divisi food service yang saat ini telah memiliki sekitar 300 orang karyawan. Dari jumlah karyawan tersebut, $40 \%$ adalah karyawan outsorcing, sedangkan $60 \%$ adalah karyawan yang langsung direkrut dan diseleksi langsung oleh manajemen Tous Les Jours Bakery, dan kemudian disebut sebagai karyawan tetap.

Penyebab dari adanya keinginan berpindah karyawan diduga menurunnya tingkat komitmen organisasi dari karyawan. Bahwa peningkatan komitmen berhubungan dengan peningkatan produktivitas dan turnover yang semakin rendah. Komitmen adalah salah satu aspek penting dari filosofi human resources management (HRM). Pengertian komitmen itu sendiri berkembang tidak lagi sekedar berbentuk kesediaan karyawan menetap di organisasi dalam jangka waktu lama, tetapi lebih dari itu, karyawan mau memberikan yang terbaik dan bahkan bersedia untuk bersikap loyal terhadap organisasi.

Bahwa budaya organisasi yang positif dapat menciptakan komitmen kepada organisasi yang tinggi.
Mengingat budaya organisasi merupakan suatu kesepakatan bersama para anggota dalam organisasi atau perusahaan sehingga mempermudah lahirnya kesepakatan yang lebih luas untuk kepentingan perorangan. Keutamaan budaya organisasi merupakan pengendali dan arah dalam membentuk sikap dan perilaku manusia yang melibatkan diri dalam suatu kegiatan organisasi. Budaya organisasi mempengaruhi produktivitas, kinerja, komitmen, kepercayaan diri dan perilaku etis. Selain itu terdapat variabel yang berasal dari diri individu itu sendiri (internal) yang memiliki peranan penting dalam meningkatkan komitmen terhadap organisasi yaitu kepuasan kerja.

Kepuasan kerja adalah sebagai sikap umum individu terhadap pekerjaannya dalam hal ini adalah karyawan. Karyawan dapat menilai seberapa puas atau tidak puas dirinya dengan pekerjaannya. Kepuasan kerja juga dapat digambarkan sebagai memiliki sikap positif terhadap pekerjaan pada diri seseorang. Buktibukti penelitian terhadap kepuasan kerja dapat dilihat dari beberapa kategori seperti kepemimpinan, kebutuhan psikologis, penghargaan atau usaha, manajemen ideologi dan nilai-nilai, serta faktor-faktor rancangan pekerjaan dan muatan kerja.

Kepuasan kerja dapat memiliki pengaruh yang substansial pada komitmen organisasional pada industri makanan cepat saji. Karyawan industri makanan cepat saji dengan tingkat kepuasan kerja tinggi lebih memiliki komitmen dibandingkan dengan karyawan dengan tingkat kepuasan kerja rendah.

Beberapa permasalahan yang menyebabkan rendahnya komitmen terhadap organisasi tersebut diatas dalam pembahasan ini dapat dirumuskan sebagai berikut: 
1. Apakah terdapat hubungan antara budaya organisasi dengan komitmen terhadap organisasi?

2. Apakah terdapat hubungan antara kepuasan kerja karyawan dengan komitmen terhadap organisasi?

3. Apakah terdapat hubungan antara budaya organisasi dan kepuasan kerja secara bersama-sama dengan komitmen terhadap organisasi?

\section{Telaah Teori dan Hipotesis \\ 2.1. Hakikat Komitmen Terhadap Organisasi}

Allen dan Meyer dalam Darmawan mendefinisikan komitmen terhadap organisasi sebagai sebuah konsep yang memiliki tiga dimensi, yaitu affective, normative, dan continue commitment. Affective commitment adalah tingkat seberapa jauh seorang karyawan secara emosi terikat, mengenal dan terlibat dalam organisasi. Continue commitment adalah suatu penilaian terhadap biaya yang terkait dengan meninggalkan organisasi. Normative commitment menunjukkan kepada tingkat seberapa jauh seseorang secara psikologis terikat untuk menjadi karyawan dari sebuah organisasi yang didasarkan pada perasaan seperti kesetiaan, affeksi, kehangatan, pemilikan, kebanggan, kesenangan, kebahagiaan dll. ${ }^{1}$ Sementara itu, pendapat yang hampir sama mengenai definisi komitmen kepada organisasi dikemukakan oleh Caldwell, Chatman dan O'Rielly yang menyatakan bahwa komitmen kepada organisasi merupakan ikatan psikologis antara karyawan dan organisasi. Komitmen organisasi ini dapat dinyatakan dalam tiga dasar kelekatan yang terpisah, yaitu compliance, identification, dan internalization. Compliance mengarah kepada kelekatan instrumental dalam bentuk reward khusus. Identification mengarah kepada kelekatan berdasarkan keinginan untuk bergabung dengan organisasi.

Sedangkan menurut Mowday, komitmen kerja merupakan istilah lain dari komitmen organisasi. Menurutnya komitmen organisasi merupakan dimensi perilaku penting yang dapat digunakan untuk menilai kecenderungan karyawan untuk bertahan sebagai anggota organisasi. Komitmen organisasi merupakan identifikasi dan keterlibatan seseorang yang relatif kuat terhadap organisasi. Komitmen organisasi merupakan keinginan anggota organisasi untuk tetap mempertahankan keanggotaannya dalam organisasi dan bersedia berusaha keras bagi pencapaian tujuan organisasi. Hal senada dikemukakan oleh Newstorm dan Davis yang menjelaskan bahwa komitmen organisasi, atau kesetiaan karyawan mencerminkan seberapa jauh karyawan merasa terikat dan terlibat dengan organisasi sehingga karyawan tersebut bersedia untuk tetap aktif dalam organisasi tersebut. Ini adalah ukuran kesediaan dari karyawan untuk tetap berada dalam organisasi tersebut dan mencerminkan keyakinan karyawan dalam misi dan tujuan organisasi, kesediaan untuk bekerja keras guna mencapai tujuan, dan memiliki niat untuk terus bekerja dalam organisasi tersebut. Komitmen yang kuat biasanya dimiliki oleh karyawan yang telah bekerja dalam waktu jangka panjang, mereka telah mengalami kesuksesan pribadi dalam organisasi. Karyawan yang memiliki komitmen akan memiliki catatan absensi yang baik, menunjukan kepatuhan pada kebijakan organisasi, dan memiliki tingkat turnover yang rendah.

Kemudian pendapat Mathias dan Jackson mengenai komitmen organisasi adalah sejauh mana karyawan percaya dan menerima tujuan organisasi dan mempunyai keinginan untuk tetap 
dengan organisasi. Hal ini berhubungan dengan sejauh mana keterlibatan karyawan untuk berkontribusi pada organisasi tersebut.

Selanjutnya, Kreitner dan Kinicki menjelaskan bahwa komitmen organisasi mencerminkan sejauh mana seorang individu mengidentifikasi dirinya dengan organisasi dan terkait dengan tujuantujuannya. Ini merupakan sikap kerja yang penting, karena karyawankaryawan yang berkomitmen diharapkan mampu menampilkan kemauan untuk bekerja keras guna mencapai tujuan organisasi dan mempunyai keinginan yang besar untuk tetap bekerja dalam organisasi tersebut.

\subsection{Hakikat Budaya Organisasi}

Menurut O'Reilly, Chatman dan Caldwell, budaya organisasi adalah suatu bentuk acuan interaksi para anggota organisasi dan bentuk acuan interaksi dengan pihak luar. Bentuk acuan itu adalah nilai, norma-norma dan aturanaturan sebagai dasar para anggota untuk berpikir dan berperilaku. Maka hakikatnya budaya organisasi adalah alat untuk menafsirkan dan mereaksi kondisi obyektif, dan budaya organisasi dapat dijadikan sumber tenaga keunggulan kompetitif.

Sedangkan menurut Robbins, budaya organisasi memiliki definisi sebagai nilai-nilai dominan yang didukung oleh organisasi atau falsafah yang menuntun kebijaksanaan organisasi terhadap pegawai dan pelanggan, atau cara pekerjaan dilakukan ditempat kerja, atau asumsi dan kepercayaan dasar yang terdapat di antara anggota organisasi.

Pendapat yang sama dikemukakan oleh Schein yang menjelaskan bahwa budaya organisasi terdiri dari asumsiasumsi dasar yang dipelajari baik sebagai hasil memecahkan masalah yang timbul dalam proses penyesuaian dengan lingkungan, maupun sebagai hasil memecahkan masalah yang timbul dari dalam organisasi, antar unit-unit organisasi yang berkaitan dengan integrasi. Budaya timbul sebagai hasil belajar bersama dari para anggota organisasi agar tetap bertahan. Asumsiasumsi dasar yang dianggap absah diajarkan kepada anggota-anggota baru sebagai cara yang tepat dalam hal mengamati, memikirkan dan merasakan dalam hubungannya dengan masalahmasalah tersebut.

Kemudian

Sedarmayanti mendefinisikan budaya organisasi sebagai sebuah keyakinan, sikap dan nilai yang umumnya dimiliki, yang timbul dalam organisasi, lebih lanjut dijelaskan budaya adalah cara kita melakukan sesuatu di dalam suatu organisasi. Pola nilai, norma keyakinan, sikap dan asumsi mungkin tidak diungkapkan, tetapi akan membentuk cara orang berperilaku dalam melaksanakan sesuatu. Nilai mengacu kepada apa yang diyakini merupakan hal penting mengenai cara karyawan dan organisasi berperilaku. Norma adalah peraturan tidak tertulis mengenai perilaku. Budaya organisasi merupakan aspek subjektif dari apa yang terjadi di dalam organisasi. Hal ini mengacu kepada abstraksi, seperti nilai dan norma yang meliputi seluruh atau sebagian dari bisnis.

\subsection{Hakikat Kepuasan Kerja}

Spector mendefinisikan kepuasan kerja sebagai sikap yang merefleksikan bagaimana perasaan evaluatif individu mengenai pekerjaannya, baik secara keseluruhan maupun dari berbagai aspek pekerjaannya. Perasaan tersebut berkisar antara kesukaan atau kepuasan terhadap pekerjaannya ataupun ketidaksukaan atau ketidakpuasan terhadap pekerjaannya. Selanjutnya Howel dan Dipboye mendefinisikan kepuasan kerja sebagai hasil keseluruhan dari derajat 
rasa suka atau tidak sukanya tenaga kerja terhadap berbagai aspek dari pekerjaannya. Dengan kata lain kepuasan kerja mencerminkan sikap tenaga kerja terhadap pekerjaannya.

Sedangkan menurut Robbins, kepuasan kerja adalah sikap umum terhadap pekerjaan seseorang yang menunjukkan perbedaan antara jumlah yang diterima pekerja dan jumlah yang mereka yakini seharusnya mereka terima.

Pendapat yang sama dikemukakan oleh Organ dan Hamner yang menjelaskan bahwa kepuasan kerja merupakan sikap seseorang terhadap pekerjaannya. Hal ini merupakan kumpulan komplek keyakinan dan pengetahuan, emosi (perasaan, sentimen, evaluasi) dan kecenderungan perilaku. Seseorang dengan tingkat kepuasan kerja yang tinggi memiliki sikap yang sangat positif tentang pekerjaannya, dan sebaliknya orang yang merasa tidak puas dengan pekerjaannya akan memiliki sikap negatif terhadap pekerjaannya tersebut.

\subsection{Hipotesis Penelitian}

Hipotesis penelitian ini adalah sebagai berikut :

1. Terdapat hubungan positif antara budaya organisasi dengan komitmen terhadap organisasi.

2. Terdapat hubungan positif antara kepuasan kerja dengan komitmen terhadap organisasi.

3. Terdapat hubungan positif antara budaya organisasi dan kepuasan kerja secara bersama-sama dengankomitmen terhadap organisasi.

\section{Konstelasi Penelitian}

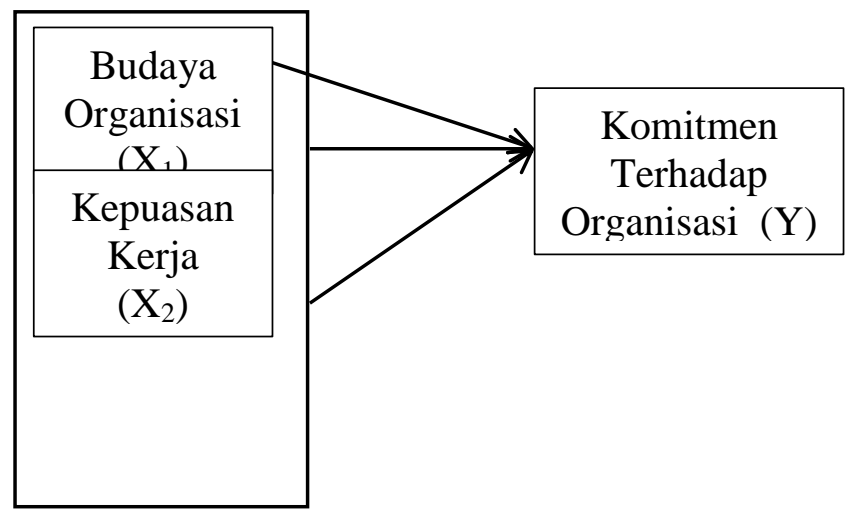

Gambar 1.

III. Metodologi Penelitian

Metode yang digunakan dalam penelitian ini adalah dengan menggunakan bentuk penelitian deskriptif dengan analisis data kuantitatif. Penelitian deskriptif yaitu bentuk penelitian yang memusatkan perhatian pada masalah-masalah atau fenomena yang bersifat aktual pada saat penelitian dilakukan kemudian menggambarkan fakta-fakta tentang masalah yang diselidiki sebagaimana adanya diiringi dengan interpretasi yang rasional dan akurat. Data yang digunakan merupakan data kuantitatif yang berasal dari hasil survei berupa penyebaran kuisioner kepada sampel karyawan Kitchen Staff Tous Les Jours Bakery yang dipilih dengan metode stratified random sampling. Sebelum digunakan data tersebut diuji validitasnya dengan metode korelasi 
pearson dan reabilitasnya dengan menggunakan metode alpha cronbach. Uji persyaratan analisis dilakukan dengan uji normalitas, uji homogenitas dan uji linearitas data.

Uji hipotesis dilakukan dengan menggunakan metode koefisien korelasi sebagai berikut:

1. Hubungan antara budaya organisasi dengan komitmen terhadap organisasi, pengujiannya dilakukan dengan teknik korelasi sederhana untuk melihat kekuatan hubungan antara variabel budaya organisasi (X1) dengan komitmen terhadap organisasi (Y).

py1 = koefisien korelasi antara variabel X1 dengan variabel $Y$.

2. Hubungan antara kepuasan kerja dengan komitmen terhadap organisasi, pengujiannya dilakukan dengan teknik korelasi sederhana untuk melihat kekuatan hubungan antara variabel kepuasan kerja (X2) dengan komitmen terhadap organisasi (Y).

คेy2 $=$ korelasi antara variabel $\mathrm{X} 2$ dengan variabel $\mathrm{Y}$.

3. Hubungan antara budaya organisasi dan kepuasan kerja secara bersama-sama dengan komitmen terhadap organisasi, pengujiannya dilakukan dengan teknik korelasi ganda dan Product Moment Corelation. Untuk melihat kekuatan hubungan antara variabel budaya organisasi (X1) dan variabel kepuasan kerja (X2) secara bersama-sama dengan komitmen terhadap organisasi (Y).

p’y.1.2 = korelasi antara variabel $\mathrm{X} 1$ dengan $\mathrm{X} 2$ secara bersamasama dengan variabel $Y$

\section{HASIL DAN PEMBAHASAN \\ 4.1. Uji Validitas}

Suatu item dinyatakan valid jika $r$ hitung > $r$ tabel. Dari hasil uji validitas dengan korelasi pearson menggunakan SPSS 16 diperoleh hasil:

1. Untuk variabel komitmen terhadap organisasi, dari 40 item pertanyaan diperoleh jumlah item yang valid sebanyak 26 item.

2. Untuk variabel budaya organisasi, dari 40 item pertanyaan diperoleh jumlah item yang valid sebanyak 22 item.

3. Untuk variabel kepuasan kerja, dari 40 item pertanyaan diperoleh jumlah item yang valid sebanyak 27 item.

\subsection{Uji Reliabilitas}

Suatu variabel dinyatakan reliabel jika nilai alpha cronbach $\geq 0,7$. Dari hasil uji reliabilitas dengan metode alpha cronbach menggunakan SPSS 16 diperoleh nilai alpha cronbach untuk variabel komitmen terhadap organisasi 0,795 ; budaya organisasi 0,852 ; dan variabel kepuasan kerja 0,773. Dengan demikian semua item variabel dinyatakan reliabel.

\subsection{Uji Normalitas}

Data suatu variabel dinyatakan terdistribusi normal jika derajat signifikansi dari hasil One-Sample Kolmogorov Smirnov Test > 0,05. Dari hasil uji One-Sample Kolmogorov Smirnov diperoleh derajat signifikansi variabel komitmen terhadap organisasi 0,742 ; budaya organisasi 0,559 ; kepuasan kerja 0,444. Dengan demikian semua item variabel dinyatakan terdistribusi normal.

\subsection{Uji Homogenitas}

Homogenitas varians data Komitmen Terhadap Organisasi (Y) atas Budaya Organisasi $\left(\mathrm{X}_{1}\right)$ diuji dengan menggunakan uji bartlett. Berdasarkan hasil perhitungan diperoleh nilai $\chi_{\text {hitung }}^{2}=$ 8,35 , sedangkan $\chi_{\text {tabel }}^{2}=126,57$. Persyaratan data homogen adalah $\chi^{2}$ hitung $<\quad \chi_{\text {tabel, dengan demikian data }}^{2}$ 
Komitmen Terhadap Organisasi (Y) dan data Budaya Organisasi $\left(\mathrm{X}_{1}\right)$ berasal dari populasi yang memiliki varians yang sama (homogen)

Homogenitas varians data Komitmen Terhadap Organisasi (Y) atas Kepuasan Kerja $\left(\mathrm{X}_{2}\right)$ diuji dengan menggunakan uji bartlett. Berdasarkan hasil perhitungan diperoleh nilai $\chi_{\text {hitung }}^{2}=$ 0,20, sedangkan $\chi_{\text {tabel }}^{2}=126,57$. Persyaratan data homogen adalah $\chi^{2}$ hitung $<\quad \chi_{\text {tabel, }}^{2}$ dengan demikian data Komitmen Terhadap Organisasi (Y) dan data Kepuasan Kerja $\left(\mathrm{X}_{2}\right)$ berasal dari populasi yang memiliki varians yang sama (homogen).

\subsection{Uji Linearitas}

Skor variabel bebas dinyatakan linear terhadap variabel terikat jika hasil uji linearitas memiliki derajat signifikansi $<0,05$. Dari hasil uji linearitas dengan menggunakan SPSS 16 diperoleh derajat signifikansi uji linearitas variabel budaya organisasi dengan komitmen terhadap organisasi 0,001; dan variabel kepuasan kerja dengan komitmen terhadap organisasi 0,000; dengan demikian semua data variabel bebas dinyatakan linear terhadap variabel terikat.

\subsection{Uji Hipotesis}

\section{Hubungan antara Budaya Organisasi $\left(\mathrm{X}_{1}\right)$ dengan Komitmen terhadap Perusahaan (Y)}

Perumusan hipotesis pertama pada penelitian ini adalah terdapat hubungan positif antara budaya organisasi $\left(\mathrm{X}_{1}\right)$ dengan komitmen terhadap organisasi (Y). Setelah dilakukan pengujian persyaratan analisa melalui uji normalitas, homogenitas dan linieritas didapatkan perhitungan hubungan fungsional atas kedua variabel budaya organisasi $\left(\mathrm{X}_{1}\right)$ dengan komitmen terhadap organisasi (Y) diperoleh hasil sebagai berikut:

a. Sesuai dengan hipotesis statistik, maka hubungan antara budaya organisasi dengan komitmen terhadap organisasi dengan menggunakan teknik korelasi product moment diperoleh koefisien korelasi $\mathrm{r}_{\mathrm{y} .1}=0,336>$ $\mathrm{r}_{\text {tabel }}\left(\mathrm{r}_{\text {tabel }}=0,176\right.$ pada $\alpha=0,05$ dan $r_{\text {tabel }}=0,230$ pada $\left.\alpha=0,01\right)$. Hubungan keduanya signifikan karena $\mathrm{Sig}=0,001$ nilai ini identik dengan $p$-value, dimana nilai $\mathrm{p}$-value lebih kecil dari $\alpha$ $(0,05)$. Dengan demikian $\mathrm{H}_{0}$ ditolak dan $\mathrm{H}_{1}$ diterima, berarti terdapat hubungan positif dan signifikan antara budaya organisasi $\left(\mathrm{X}_{1}\right)$ dengan komitmen terhadap organisasi (Y).

b. Kontribusi budaya organisasi $\left(\mathrm{X}_{1}\right)$ dengan komitmen terhadap organisasi (Y) dihitung berdasarkan koefisien determinasi yaitu $r^{2}=\left(r_{y \cdot 1.2}\right)^{2}=0,113$. Berarti variabel budaya organisasi membentuk kontribusi sebesar $11,3 \%$ terhadap komitmen terhadap organisasi (Y).

c. Hubungan Fungsional antara budaya organisasi dengan komitmen terhadap organisasi dihitung menggunakan teknik analisis regresi $\hat{Y}=54,338+$ $0,448 X_{1}$. Pengujian signifikan persamaan regresi diperoleh kesimpulan bahwa $\quad \mathrm{F}_{\text {hitung }}=$ $12,853>\mathrm{F}_{\text {tabel }}\left(\mathrm{F}_{\text {tabel }}=3,07\right.$ pada $\alpha$ $=0,05$ dan $F_{\text {tabel }}=4,78$ pada $\alpha=$ $0,01)$. Berarti persamaan regresi tersebut sangat signifikan dengan demikian variabel budaya organisasi dapat digunakan untuk memprediksi komitmen terhadap organisasi.

d. Untuk menguji hipotesis bahwa terdapat hubungan positif antara 
variabel $\mathrm{X}_{1}$ dengan $\mathrm{Y}$ diperlukan uji signifikansi koefisien korelasi yaitu dengan uji $t$. Kriteria pengujian signifikansi koefisien korelasi adalah jika $t_{\text {hitung }}>t_{\text {tabel }}$. Dari table 23 Coefficients diperoleh $\mathrm{t}_{\text {hitung }}=3,585$, tingkat Sig $=0,05$ dan $\mathrm{N}-1$ atau $103-1$
$=102$ didapat $t_{\text {tabel }}=1,659$.

Ternyata bahwa nilai $t_{\text {hitung }}>t_{\text {tabel }}$ atau 3,585 >1,659, berarti budaya organisasi $\left(X_{1}\right)$ sangat signifikan terhadap komitmen terhadap organisasi (Y).

Tabel 1

Hasil Perhitungan Uji Signifikansi Korelasi Variabel $\mathrm{X}_{1}$ dan Y

\begin{tabular}{|c|c|c|c|c|c|}
\hline \multirow{2}{*}{$\begin{array}{c}\text { Koefisien } \\
\text { Korelasi }\end{array}$} & $\mathrm{dk}$ & $\mathrm{t}_{\text {hitung }}$ & \multicolumn{2}{|c|}{$\mathrm{t}_{\text {tabel }}$} & \multirow{2}{*}{$\begin{array}{c}\alpha= \\
\text { Kesimpulan }\end{array}$} \\
\hline 0,336 & 102 & $3,585^{* *}$ & 1,659 & 1,983 & \\
\hline & & & $\begin{array}{c}\text { Sangat } \\
\text { Signifikan }\end{array}$ \\
\hline
\end{tabular}

Keterangan : $* *=$ Sangat signifikan

Yang artinya bahwa budaya organisasi merupakan makna yang didapat mengenai sejumlah pemahaman penting karyawan terhadap nilai, norma dan aturan yang dimiliki bersama oleh anggota organisasi. Yang diukur melalui karakteristik budaya organisasi yaitu inovasi dalam pengambilan resiko, stabilitas dan keamanan, penghargaan kepada orang, orientasi hasil, orientasi tim dan kolaborasi, keagresifan dan persaingan bila dijalankan dengan baik maka secara otomatis akan berpengaruh positif terhadap komitmen terhadap organisasi yaitu karyawan akan bersikap dan perilaku serta kecenderungan karyawan untuk tertarik dengan tujuan, nilai dan sasaran organisasi yang ditunjukkan dengan adanya penerimaan individu atas nilai dan tujuan organisasi serta memiliki keinginan untuk berafiliasi dengan organisasi dan kesediaan bekerja keras untuk organisasi sehingga membuat individu betah dan tetap ingin bertahan di organisasi tersebut demi tercapainya tujuan dan kelangsungan organisasi.
Hal ini sesuai dengan penelitian Susanto bahwa terdapat hubungan yang positif budaya organisasi dengan komitmen terhadap organisasi koefisien regresi sebesar 3,346, p 0,000 $<0,05$. Dengan demikian disimpulkan terdapat pengaruh yang positif.

\section{Hubungan antara Kepuasan \\ Kerja $\left(\mathbf{X}_{2}\right)$ dengan Komitmen terhadap Perusahaan (Y)}

Perumusan hipotesis kedua pada penelitian ini adalah terdapat hubungan positif antara kepuasan kerja $\left(\mathrm{X}_{2}\right)$ dengan komitmen terhadap organisasi (Y). Setelah dilakukan pengujian persyaratan analisa melalui uji normalitas, homogenitas dan linieritas didapatkan perhitungan hubungan fungsional atas kedua variabel kepuasan kerja $\left(\mathrm{X}_{2}\right)$ dengan komitmen terhadap organisasi (Y) diperoleh hasil sebagai berikut :

a. Sesuai dengan hipotesis statistik, maka hubungan antara kepuasan kerja dengan komitmen terhadap organisasi dengan menggunakan teknik korelasi product moment diperoleh koefisien korelasi $\mathrm{r}_{\mathrm{y} .2}=$ 
$0,466>\mathrm{r}_{\text {tabel }}\left(\mathrm{r}_{\text {tabel }}=0,176\right.$ pada $\alpha$ $=0,05$ dan $r_{\text {tabel }}=0,230$ pada $\alpha=$ 0,01). Hubungan keduanya signifikan karena $\mathrm{Sig}=0,000$ nilai ini identik dengan $p$-value, dimana nilai p-value lebih kecil dari $\alpha$ $(0,05)$. Dengan demikian $\mathrm{H}_{0}$ ditolak dan $\mathrm{H}_{1}$ diterima, berarti terdapat hubungan positif dan signifikan antara kepuasan kerja $\left(\mathrm{X}_{2}\right)$ dengan komitmen terhadap organisasi (Y).

b. Kontribusi kepuasan kerja $\left(\mathrm{X}_{2}\right)$ dengan komitmen terhadap organisasi (Y) dihitung berdasarkan koefisien determinasi yaitu $r^{2}=\left(r_{y .2}\right)^{2}=0,217$. Berarti variabel kepuasan kerja membentuk kontribusi sebesar 21,7\% terhadap komitmen terhadap organisasi (Y).

c. Hubungan fungsional antara kepuasan kerja dengan komitmen terhadap organisasi dihitung menggunakan teknik analisis regresi $\hat{\mathrm{Y}}=43,852+0,487 \mathrm{X}_{2}$.
Pengujian signifikan persamaan regresi diperoleh kesimpulan bahwa $\quad F_{\text {hitung }}=28,046>F_{\text {tabel }}$ $\left(F_{\text {tabel }}=3,07\right.$ pada $\alpha=0,05$ dan $\mathrm{F}_{\text {tabel }}=4,78$ pada $\left.\alpha=0,01\right)$. Berarti persamaan regresi tersebut sangat signifikan dengan demikian variabel kepuasan kerja dapat digunakan untuk memprediksi komitmen terhadap organisasi.

d. Untuk menguji hipotesis bahwa terdapat hubungan positif antara variabel $\mathrm{X}_{2}$ dengan $\mathrm{Y}$ diperlukan uji signifikansi koefisien korelasi yaitu dengan uji $t$. Kriteria pengujian signifikansi koefisien korelasi adalah jika $t_{\text {hitung }}>t_{\text {tabel }}$. Dari table 24 Coefficients diperoleh $t_{\text {hitung }}=5,296$, tingkat Sig $=0,05$ dan $\mathrm{N}-1$ atau $103-1$ $=102$ didapat $t_{\text {tabel }}=1,659$. Ternyata bahwa nilai $t_{\text {hitung }}>\mathrm{t}_{\text {tabel }}$ atau 5,296 > 1,659, berarti kepuasan kerja $\left(\mathrm{X}_{2}\right)$ sangat signifikan terhadap komitmen terhadap organisasi (Y).

Tabel 2

Hasil Perhitungan Uji Signifikansi Korelasi Variabel $\mathrm{X}_{2}$ dan $\mathrm{Y}$

\begin{tabular}{|c|c|c|c|c|c|}
\hline \multirow{2}{*}{$\begin{array}{c}\text { Koefisien } \\
\text { Korelasi }\end{array}$} & \multirow{2}{*}{$\mathrm{dk}$} & $\mathrm{t}_{\text {hitung }}$ & $\begin{array}{c}\alpha= \\
\mathrm{t}\end{array}$ & $\begin{array}{c}\alpha= \\
\text { Kabel }\end{array}$ & \multirow{2}{*}{ Kesimpulan } \\
\hline 0,466 & 102 & $5,296^{* *}$ & 1,659 & 1,983 & $\begin{array}{c}\text { Sangat } \\
\text { Signifikan }\end{array}$ \\
\hline
\end{tabular}

Keterangan : $* *=$ Sangat signifikan

Yang artinya bahwa kepuasan kerja atau indikator yang didapat tentang sikap karyawan terkait kepuasan akan kesesuaian gaji dan beban kerja, kepuasan akan adanya kesempatan promosi, kepuasan akan interaksi dengan atasan, kepuasan akan fasilitas yang diberikan perusahaan, kepuasan akan prosedur dan peraturan yang ada di perusahaan berpengaruh terhadap komitmen para karyawannya terhadap organisasi dengan cara karyawan bersikap dan perilaku dalam berorganisasi, karyawan tertarik dengan tujuan yang telah direncanakan organisasi, karyawan menunjukkan keinginan untuk berafiliasi dengan organisasi dan kesediaan bekerja keras untuk organisasi.

\section{Hubungan antara Budaya Organisasi $\left(X_{1}\right)$ dan Kepuasan}


Kerja $\left(\mathrm{X}_{2}\right)$ secara bersama-sama dengan Komitmen Terhadap Organisasi ( $Y$ ).

Hipotesis yang ketiga yang diujikan adalah terdapatnya hubungan positif Budaya Organisasi $\left(\mathrm{X}_{1}\right)$ dan Kepuasan Kerja $\left(\mathrm{X}_{2}\right)$ secara bersamasama dengan Komitmen Terhadap Organisasi (Y).

a. Sesuai dengan hipotesis statistik, maka hubungan antara Budaya Organisasi $\left(\mathrm{X}_{1}\right)$ dan Kepuasan Kerja $\left(X_{2}\right)$ secara bersama-sama dengan Komitmen Terhadap Organisasi (Y) dengan menggunakan teknik korelasi product moment diperoleh koefisien korelasi $\mathrm{r}_{\mathrm{y} .1 .2}=0,507>$ $\mathrm{r}_{\text {tabel }}\left(\mathrm{r}_{\text {tabel }}=0,176\right.$ pada $\alpha=0,05$ dan $r_{\text {tabel }}=0,230$ pada $\left.\alpha=0,01\right)$. Hubungan keduanya signifikan karena $\mathrm{Sig}=0,000$ nilai ini identik dengan $p$-value, dimana nilai $p$-value lebih kecil dari $\alpha$ $(0,05)$. Dengan demikian $\mathrm{H}_{0}$ ditolak dan $\mathrm{H}_{1}$ diterima, berarti terdapat hubungan positif dan signifikan antara Budaya Organisasi $\left(\mathrm{X}_{1}\right)$ dan Kepuasan Kerja $\left(\mathrm{X}_{2}\right)$ secara bersama-sama dengan Komitmen Terhadap Organisasi (Y).

b. Kontribusi Budaya Organisasi $\left(\mathrm{X}_{1}\right)$ dan Kepuasan Kerja $\left(X_{2}\right)$ secara bersama-sama dengan Komitmen Terhadap Organisasi (Y) dihitung berdasarkan koefisien determinasi yaitu $\mathrm{r}^{2}=\left(\mathrm{r}_{\mathrm{y} \cdot 1.2}\right)^{2}=0,257$. Berarti variabel Budaya Organisasi $\left(\mathrm{X}_{1}\right)$ dan Kepuasan Kerja $\left(\mathrm{X}_{2}\right)$ membentuk kontribusi sebesar 25,7\% terhadap Komitmen Terhadap Organisasi (Y).

c. Hubungan Fungsional antara Budaya Organisasi $\left(\mathrm{X}_{1}\right)$ dan Kepuasan Kerja $\left(\mathrm{X}_{2}\right)$ secara bersama-sama dengan Komitmen Terhadap Organisasi (Y) dihitung menggunakan teknik analisis regresi $\hat{Y}=50,004-0,622 X_{1}+$ $0,928 X_{2}$. Pengujian signifikan persamaan regresi diperoleh kesimpulan bahwa $\quad \mathrm{F}_{\text {hitung }}=$ $17,312>\mathrm{F}_{\text {tabel }}\left(\mathrm{F}_{\text {tabel }}=3,07\right.$ pada $\alpha$ $=0,05$ dan $F_{\text {tabel }}=4,78$ pada $\alpha=$ $0,01)$. Berarti persamaan regresi tersebut sangat signifikan dengan demikian variabel Budaya Organisasi $\left(\mathrm{X}_{1}\right)$ dan Kepuasan Kerja $\left(\mathrm{X}_{2}\right)$ dapat digunakan untuk memprediksi Komitmen Terhadap Organisasi.

d. Untuk menguji hipotesis bahwa terdapat hubungan positif antara variabel $\mathrm{X}_{1}$ dan $\mathrm{X}_{2}$ secara bersama-sama dengan $Y$ diperlukan uji signifikansi koefisien korelasi yaitu dengan uji F. Kriteria pengujian signifikansi koefisien korelasi adalah jika $\mathrm{F}_{\text {hitung }}>\mathrm{F}_{\text {tabel. }}$. Setelah diuji diperoleh hasil sebagai berikut :

Tabel 3

Hasil Perhitungan Uji Signifikansi Korelasi Variabel $\mathrm{X}_{1}$ dan $\mathrm{X}_{2}$ secara bersama-sama dengan variabel $\mathrm{Y}$

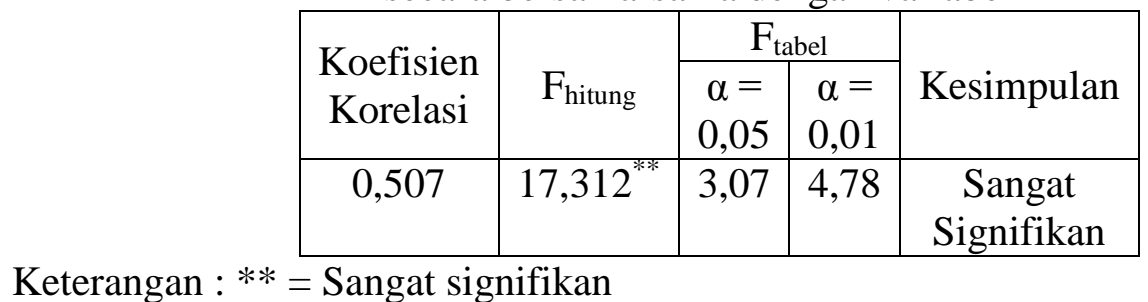





\section{Penutup}

\subsection{Kesimpulan}

Terlepas dari kelemahankelemahan dan kekurangan penelitian ini, baik dari segi metodologi maupun dari segi obyeknya, namun beberapa hasil dapat disimpulkan sebagai berikut:

1. Budaya organisasi memilik hubungan positif dengan komitmen karyawan terhadap organisasi dan kekuatan hubungannya lemah. Hal ini berarti bahwa komitmen terhadap organisasi pada Karyawan Tous Les Jours Bakery sangat ditentukan oleh Budaya Organisasi. Budaya Organisasi yang baik akan mengakibatkan tinginya komitmen karyawan terhadap organisasi dan sebaliknya jika budaya organisasi buruk maka komitmen karyawan terhadap organisasi juga rendah.

2. Kepuasan kerja memiliki hubungan positif dengan komitmen karyawan terhadap organisasi dan kekuatan hubungannya sedang. Hal ini berarti bahwa komitmen terhadap organisasi pada Karyawan Tous Les Jours Bakery sangat ditentukan oleh kepuasan kerja. Kepuasan kerja yang tinggi akan mengakibatkan tingginya komitmen karyawan terhadap organisasi dan sebaliknya jika kepuasan kerja rendah maka komitmen karyawan terhadap organisasi juga rendah.

3. Budaya organisasi dan kepuasan kerja secara bersama-sama memiliki hubungan positif dengan komitmen terhadap perusahaan dan kekuatan hubungannya sedang. Jadi apabila budaya organisasi dan kepuasan kerja ditingkatkan secara otomatis komitmen terhadap organisasi pada Karyawan Tous Les Jours Bakery akan meningkat dan sebaliknya jika jika budaya organisasi dan kepuasan kerja rendah maka komitmen terhadap organisasi pada Karyawan Tous Les Jours Bakery juga rendah.

\subsection{Saran}

Berdasarkan kesimpulan dan implikasi penelitian, beberapa saran dapat dikemukakan sebagai berikut:

1. Saran untuk meningkatkan komitmen terhadap organisasi

Karyawan dalam perusahaan merupakan faktor utama dalam pelaksanaan untuk mencapai tujuan perusahaan. Oleh sebab itu, karyawan dalam perusahaan harus dapat meningkatkan komitmen terhadap organisasi, karena dengan komitmen terhadap organisasi yang tinggi akan tercapai tujuan perusahaan. Hal-hal yang dapat dilakukan dalam meningkatkan komitmen terhadap organisasi adalah :

a. Perusahaan harus mampu menjalin ikatan dengan para karyawannya baik secara prosedural kerja maupun secara sosial.

b. Organisasi harus mampu menghargai pekerjaan yang dikerjakan oleh para karyawannya sehingga karyawan akan merasa betah untuk bekerja dalam oraganisasi dan tidak akan meninggalkan organisasi.

c. Organisasi harus mampu menumbuhkan kesadaran karyawan bahwa komitmen terhadap organisasi merupakan hal yang memang seharusnya dilakukan, karena dampak dari komitmen terhadap organisasi akan 
mempermudah tercapainya suatu tujuan yang telah direncanakan organisasi.

2. Saran untuk meningkatkan budaya organisasi:
a. Organisasi
mampu
melakukan inovasi-inovasi
baru dan mengembangkan
proses pengambilan resiko
sehingga seluruh kegiatan pekerjaan resikonya sedikit.
b. Organisasi harus mampu menciptakan stabilitas dan keamanan kepada para karyawannya, sehingga para karyawan merasa terjamin atau mendapatkan jaminan keselamatan dan keamanan dalam bekerja sehingga para karyawan dapat menyelesaikan yang telah ditetapkan organisasi sesuai dengan SOP yang berlaku.
c. Para karyawan sebaiknya diberi pelatihan-pelatihan atau masukan-masukan dari organisasi mengenai pentingnya menghargai ide atau pekerjaan sesama rekan kerja, karena semua itu ada keterkaitan dalam mencapai tujuan organisasi.

d. Organisasi mampu merencanakan, mengorganisasi, menggerakan dan mengawasi para karyawan yang bertujuan untuk mencapai orientasi hasil yang telah ditetapkan.

e. Organisasi mampu menciptakan orientasi tim dan kolaborasi antar para karyawan dengan tujuan mempermudah menyamakan tujuan bersama.

f. Organisasi mampu menumbuhkan keagresifan para karyawan dan meningkatkan persaingan positif dalam hal bekerja.

3. Saran untuk meningkatkan kepuasan kerja

a. Organisasi harus konsisten dalam kesesuaian jumlah gaji, tanggal penerimaan gaji sesuai dengan ketentuan yang telah diatur oleh organisasi.

b. Organisasi memberikan kesempatan berupa promosi berupa peningkatan jenjang karir secara terbuka pada setiap karyawan yang berprestasi dalam hal bekerja.

c. Organisasi mampu menjalin interaksi antara pegawai dengan para atasan sehingga terjalin suasana yang harmonis.

d. Organisasi memberikan fasilitas berupa sarana dan prasarana dalam menunjang pekerjaan.

e. Organisasi dan para karyawan harus mampu mentaati peraturan yang ada di organisasi.

\section{DAFTAR PUSTAKA}

Allen, NJ \& Meyer JP. "The Measurement and Attecedent of Affective, Continuance and Normative Commitment to the Organization" Journal Of Occupational Psychologi: 1990

Balay. $\mathrm{R} \&$ Ipek. C, "Teachers Perception Of Organizational Culture And Organizational Commitment In Turkish Primary Schools". Journal of World of Turks. Vol.2, No.1, 2010.

Caldwell, et.al,"Buliding Organizational Commitment: A Multifirm 
Study",Journal of Occupational Psychology, The British Psychological Society, 1992

Dipboye, R. S., Smith, C. S., \& Howell, W. C,Understanding industrial and organizational psychology: An integrated approach, Orlando: Harcourt, Brace \& Co, International Edition, 1994

Feinstein. A.H, "A Study Relationship Between Job Satisfaction And Organizational Commitment Among Restaurant Employees", 2002

Hana Chrysanti Widyastuti. “"'Hubungan Antara Budaya Organisasi Dengan Komitmen Organisasi Pada Perawat Rumah Sakit Panti Wilasa Citarum Semarang". Tesis Pascasarjana Universitas Diponegoro. 2010

Kreitner. R \& Kinicki. A, “Organizational Behaviour"(6th ed). China : Mc Graw Hill Companies, 2007

Ma'ruf. Andi Awaluddin, Deddy T Tikson dan M. Thahir Haning ."Hubungan Kepuasan Kerja Dengan Komitmen Organisasi Pegawai Dinas Tata Ruang Dan Bangunan Kota Makassar" Jurnal Universitas Hasanudin Makasar

Miner, J.B. Industrial-Organizational Psychology United States of America: McGraw-Hill.,1992

Mowday, R.T, Porter, L.W dan Steers R.M, Employee Organization Lingkages: The Psychology of Commitment, Absenteeism and Turnover London: Academic Press Inc, 2002

Organ, Dennis W. dan W. Clay Hammer. Organizational Behavior, An Applied Physhological Approach, Texas:Business Publications, 1982.
Prima Ariestonandri, Marketing Research for Beginer Yogyakarta : Andi, 2006

Robbins, P Stephen "Prinsip-Prinsip Perilaku Organisasi, edisi kelima, dialih bahasa, Halida. Jakarta : Erlangga, 2001

Robert L. Mathis \& John H. Jackson, Human Resources Management Edisi Sepuluh Jakarta : Salemba Empat, 2006

Schein, E.H. , Organizational Culture and Leadership San Fransisco : Jossey Bass 1992

Sedarmayanti, Sumber Daya Manusia dan Produktivitas Kerja, Bandung : Mandar Maju, 2007

Siswanto \& Sucipto. A, "Teori \& Perilaku Organisasi”, Sebuah Tinjauan Integratif, Malang : UIN Malang Press, 2008.

Sopiah, "Perilaku Organisasi" Yogyakarta : Andi, 2008.

Steers, R.M and Porter, L.W, Motivation and Work Behavior New York:McGraw Hill Book Co, 1991

Soedjono, "Pengaruh Kepuasan kerja Terhadap Kinerja Karyawan dan Efektivitas Organisasi",Jurnal Ekonomi Management Fakultas Ekonomi, Universitas Kristen Petra, 2002.

Spector, Paul E. Industrial and Organizational Psychology: Research anda Practice New York: John Wiley \& Sons, 2000.

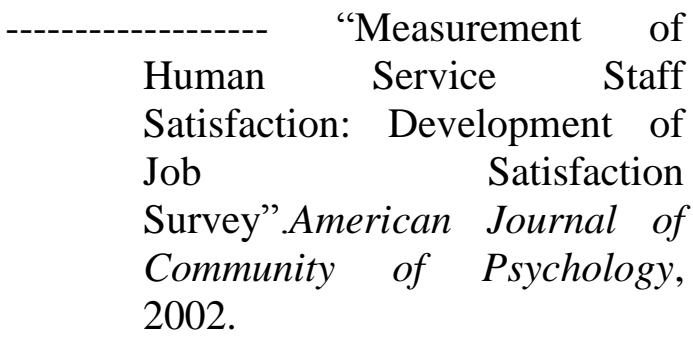

Sugiyono. Metode Penelitian Bisnis Bandung : CV Alfabeta, 2007 
"Metode Penelitian

Kuantitatif, Kualitatif, dan

R\&D”. Bandung : Alphabeta, 2009

Veithzal Rivai.Manajemen Sumber Daya Manusia Untuk Perusahaan :

Dari Teori Ke Praktik. Jakarta :

Raja Grafindo Persada, 2004.

Wirawan, Budaya dan Iklim Organisasi. Jakarta : Salemba Empat, 2007

Wu A, Chow CW, Mc. Kinnon JL \& Harisson. GL, Organizational Cultural: Association With Commitment, Job Satisfaction, Propensity to Remain \& Information Sharing in Taiwan, 2001. 